\title{
The Tamazunchale Press: A Bibliographic Checklist
}

\section{CHARLOT TE M. SM ITH}

After collecting and studying miniature books (those less than three inches in height) for over twenty years, I decided to go a step further in this fascinating pursuit by entering the publishing field. My goal was to bring some of my favorite authors, both old and new, hitherto unpublished in miniature book form, to this small format. But first I would practice by publishing a piece of my own before tackling a major author.

And so Tamazunchale Press was born early in 1983. In 1939 Tom and I had spent one night on our honeymoon in a small Mexican village, Tamazunchale, which was named, we were told, for two silver prospectors: one Thomas, the other Charlie. As this town suggested our two names, it seemed fitting to borrow it with the Mexican spelling for our press.

I had first seen the work of Joh. Enschedé en Zonen of Haarlem, Holland, printers for over 275 years, in some of the elegant yet simple tiny tomes published by Achille St. Onge, the outstanding miniature book publisher of this century, now deceased. Tom and I met with a descendant of the founder of the Enschede firm in Haarlem. They print all the stamps and paper money in Holland as well as books of all sizes. After discussing costs we selected paper, leather, end papers, and printing fonts for the printing and binding of our first publication, Book Interlude.

Nine months to a year elapse from the conception of a book until it is completed and in my hands. The selection of an appropriate story, suite of poems, or essay is determined by personal taste and length. For contemporary writers, copyright 


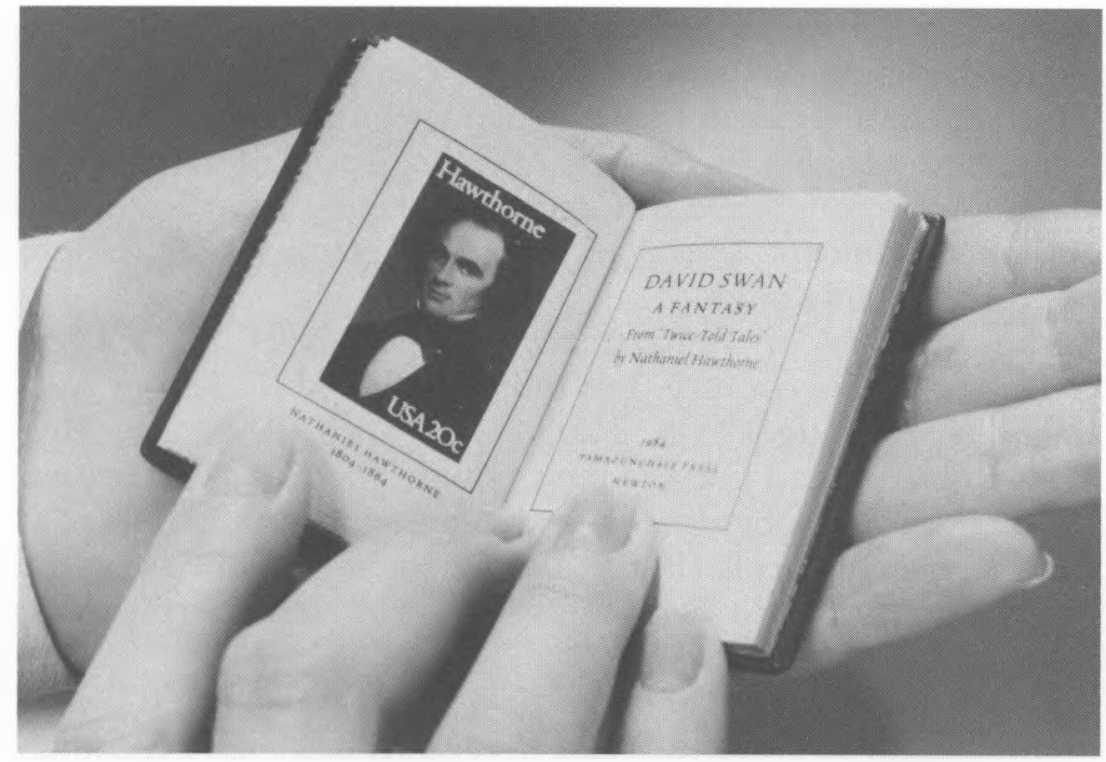

permission is negotiated and royalties paid. Colors and textures of leather for bindings are chosen, along with appropriate marbled papers for end papers. All of our books that were printed by Joh. Enschedé en Zonen made use of Trinité type and were bound by Reliure d'Art du Centre S.A. of Limoges, France. These choices are sent with the manuscript to the printer for a price quotation, which might be two or three months in coming. There is a wait of three or four months for the proof copy and an equal length of time after the corrected galley is returned before I can expect the finished books. Each copy is then examined for improper gatherings and every book is given a number on the colophon page.

Some of the books have postage stamps as frontispieces. Stamps, because of their size, make interesting and colorful illustrations for small books. The Nathaniel Hawthorne and the Pearl Buck stamps used in David Swan and My Chinese Childhood were purchased at the time of their issue at the local post office. Three stamp companies provided the older 1940 Washington 
Irving stamps for A Literary Antiquary. We saw the French postal depiction of Claude Monet's "Women in the Garden," which illustrates Claude Monet, when visiting Monet's beautiful home and gardens in Giverny, France. The Antonin Dvořák stamps were purchased in Czechoslovakia by Janet Savin, the author of Antonin Dvořák. I affix the stamps with hinges opposite the title page.

The majority of Tamazunchale Press books are sold to collectors in this country, but individuals and dealers in Australia, Japan, Yugoslavia, Hungary, France, Germany, Holland, England, and Canada have bought them as well. Several universities and libraries have purchased our miniatures for author or subject collections. The University of Iowa and the Public Library of Des Moines, as well as 50 or more collectors, have complete collections.

To my knowledge Tamazunchale Press books are the only miniature books ever published in Iowa. It has been a learning, sometimes frustrating, mostly fulfilling experience to publish these small books. 


\section{CHECKLIST}

1. BOOK INTERLUDE by Charlotte M. Smith. October 1983. Bound in full maroon leather with gold stamping, all edges gilt, Cockerell end papers. $23 / 4 \times 17 / 8^{\prime \prime} .250$ numbered and signed copies. 44 pages. Printed by Joh. Enschedé en Zonen, bound by Reliure d'Art de Centre. Iowa Authors Collection

2. AUTOGRAPHS OF MINIATURE BOOK PUBLISHERS. 95 facsimile autographs of 80 presses. December 1983. Transparent polycarbonate covers displaying title page and colophon in three colors fastened with a polyurethane loop tied with blue ribbon. 2 $1 / 16 \times 3^{\prime \prime}$. 250 numbered copies. Printed by Garner Printing Co., bound by Tamazunchale Press. xZ1033.M6A8 1983

3. DAVID SWAN by Nathaniel Hawthorne. February 1984. Bound in full dark green leather with gold stamping, all edges gilt, Cockerell end papers. $25 / 8 \times 1$ 7/8". 250 numbered copies. 37 pages. A twenty-cent Hawthorne stamp used as frontispiece. Printed by Joh. Enschedé en Zonen, bound by Reliure d'Art du Centre. xPS1872.D37 1984

4. THE MODEL E by Thomas R. Smith. May 1984. Bound in full red leather with gold stamping, Faith Harrison end papers. Four illustrations. $21 / 2 \times 2$ ". 250 numbered copies. 80 pages. Printed and bound by Tabula Rasa Press. Iowa Authors Collection

5. MY FAVORITE MINIATURE BOOK by James DeLancey, Ruth Adomeit, Robert E. Massmann, Julia Wightman, Msgr. Francis J. Weber, Virginia Schoonover, Kalman Levitan, Stanley Marcus, and Charlotte Smith. August 1984. Bound in full dark blue leather with gold stamping, all edges gilt, Cockerell end papers. $21 / 2 \times 1$ 3/4". 250 numbered copies. 88 pages. Printed by Joh. Enschedé en Zonen, bound by Reliure d'Art du Centre. xZ1033.M6M9 1984

6. CONFESSIONS OF A WILD BORE by John Updike. November 1984. Bound in full brown leather with gold stamping, all edges gilt, Cockerell end papers. $21 / 2 \times 13 / 4^{\prime \prime} .250$ numbered copies. 43 pages. Printed by Joh. Enschedé en Zonen, bound by Reliure d'Art du Centre. xPS3571.P455C57 1984

7. A HOLLANDER GARLAND, Eight Shaped Poems by John Hollander. Introduction by Charlotte M. Smith. February 1985. Bound in full blue leather with gold stamping, Faith Harrison end 


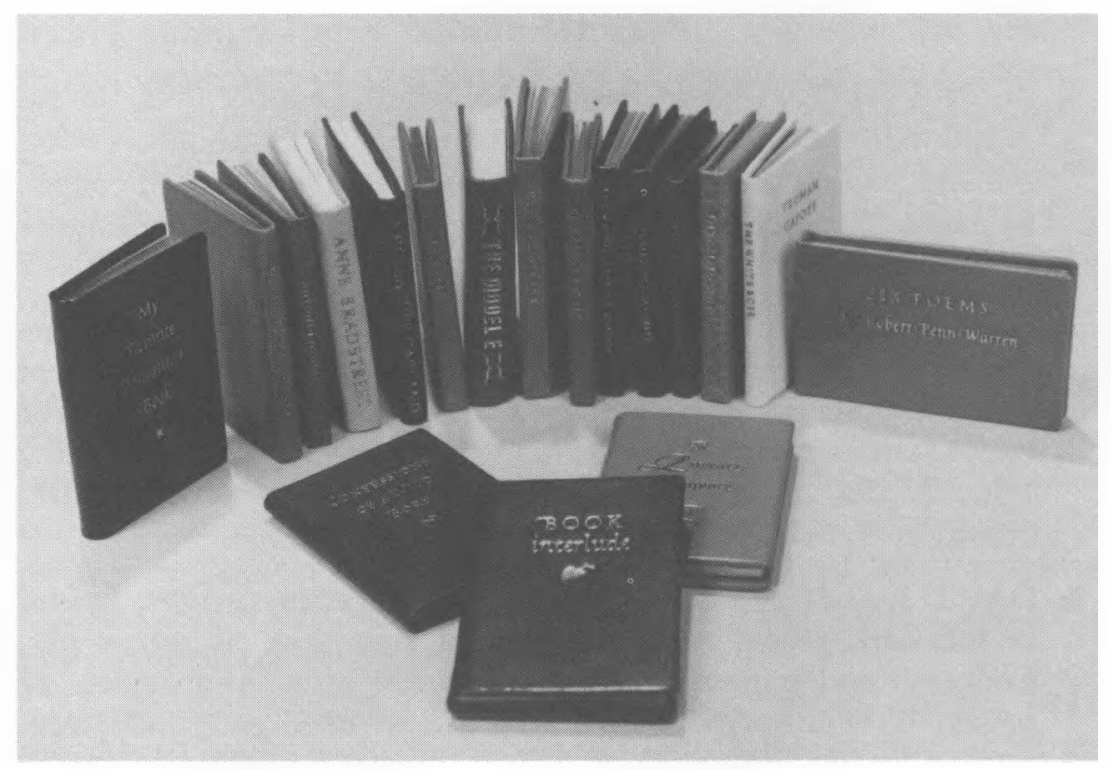

papers. $21 / 2 \times 23 / 8^{\prime \prime} .250$ numbered copies. 33 pages. Printed and bound by Tabula Rasa Press. xPS3515.O3485H65 1985

8. THE GEESE by E.B. White. May 1985. Bound in full goose gray leather with gold stamping, all edges gilt, Cockerell end papers. $21 / 2 \times 17 / 8^{\prime \prime} .250$ numbered copies. 51 pages. Printed by Joh. Enschedé en Zonen, bound by Reliure d'Art du Centre. xPS3545.H5187G4 1985

9. THE LITTLE STORE by Eudora Welty. July 1985. Bound in full light green leather with gold stamping, all edges gilt, Cockerell end papers. $21 / 2 \times 17 / 8^{\prime \prime} .250$ numbered copies. 51 pages. Printed by Joh. Enschedé en Zonen, bound by Reliure d'Art du Centre. xPS3545.E6Z473 1975

10. A LITERARY ANTIQUARY by Washington Irving. November 1985. Bound in full light brown leather with gold stamping, all edges gilt, Cockerell end papers. $21 / 2 \times 13 / 4^{\prime \prime} .250$ numbered copies. 40 pages. A 1940 Washington Irving one-cent stamp used as frontispiece. Printed by Joh. Enschedé en Zonen, bound by Reliure d'Art du Centre. xPS2057.A2T3 1984 
11. THE MANUSCRIPT by Isaac Bashevis Singer. February 1986. Bound in full red leather with gold stamping, all edges gilt, Faith Harrison end papers. 2 9/16 x 1 13/16". 250 numbered copies. 52 pages. Printed by Joh. Enschedé en Zonen, bound by Reliure d'Art du Centre. xPJ5129.S475M36 1986

12. MY CHINESE CHILDHOOD by Pearl S. Buck. May 1986. Bound in full earth brown leather with gold stamping, embossed oriental motif, three earth brown illustrations by Corinne Guiney, all edges gilt, Faith Harrison end papers. A five-cent Pearl Buck postage stamp used as frontispiece. $21 / 2 \times 13 / 4^{\prime \prime} .250$ numbered copies. 38 pages. Printed in two colors by Joh. Enschedé en Zonen, bound by Reliure d'Art du Centre. xPS3503.U198Z47 1986

13. POEMS AND MEDITATIONS by Anne Bradstreet, with introduction by Polly Kemp. July 1986 . Bound in full Puritan tan leather with gold stamping, Faith Harrison end papers. $21 / 2 \times 2$ 1/8". 250 numbered copies. 38 pages. Two illustrations by Polly Kemp in color printed by letterpress. Printed and bound by Tabula Rasa Press. xPS711.A4 1986

14. CLAUDE MONET by Janet Savin. November 1986. Bound in lavender leather with facsimile of Monet's signature in gold, all edges gilt, Faith Harrison end papers. 2 11/16 x 2 3/16". 250 numbered copies. 61 pages. A French postage stamp depicting "Women in the Garden" used as frontispiece. Printed by Joh. Enschedé en Zonen, bound by Reliure d'Art du Centre. xND553.M7S36 1986

15. THE ARISTOCRAT by Maya Angelou. March 1987. Bound in full orange leather with gold stamping, all edges gilt, Faith Harrison end papers. $29 / 16 \times 17 / 8^{\prime \prime} .250$ numbered copies. 48 pages. Printed by Joh. Enschedé en Zonen, bound by Reliure d'Art du Centre. xPS3551.N584A9 1986

16. THE WHITE ROSE by Truman Capote. July 1987. Bound in full white vellum with gold stamping, with blind stamped rose, all edges gilt, Cockerell end papers. $21 / 2 \times 13 / 4^{\prime \prime} .250$ numbered copies. 31 pages. A colored illustration of the white rose is tipped in. Printed by Joh. Enschedé en Zonen, bound by Reliure d'Art du Centre. xPS3505.A59W4 1987 
17. SIX POEMS by Robert Penn Warren. November 1987. Bound in full light blue leather with gold stamping, all edges gilt, Faith Harrison end papers. $15 / 8 \times 21 / 2^{\prime \prime} .250$ numbered copies. 58 pages. Printed by Joh. Enschedé en Zonen, bound by Reliure d'Art du Centre. xPS3545.A748A6 1987

18. THE RUSSIAN ICON by Ann Bahar. March 1988. Bound in full red leather with gold stamping. An illustration of the nineteenthcentury Virgin Gruzenskaya printed in red is tipped in. Faith Harrison end papers, all edges gilt. $23 / 8 \times 15 / 8$ ". 250 numbered copies. 30 pages. Printed by Joh. Enschedé en Zonen, bound by Reliure d'Art du Centre. xN8189.R9B35 1988

19. PUBLISHER'S FAVORITE by Ward Schori, Miriam Irwin, Carol Cunningham, Frank Anderson, Mary Helen and Glen Dawson, and Eleanor Irwin. July 1988. Bound in full dark blue leather with gold stamping, all edges gilt, Faith Harrison end papers. $21 / 2 \times 1$ $7 / 8^{\prime \prime} .250$ numbered copies. 52 pages. Printed by Joh. Enschedé en Zonen, bound by Reliure d'Art du Centre. xZ1033.M6P8 1988

20. ANTONIN DVOŘÁK by Janet Savin. November 1988. Bound in full light brown leather with gold stamping, all edges gilt, Faith Harrison end papers. Czech Dvorák stamp used as frontispiece. 2 1/2 x 1 13/16". 250 numbered copies. 48 pages. Printed by Joh. Enschedé en Zonen, bound by Reliure d'Art du Centre. xML410.D99S28 1988 